\title{
Correction to: Integrin-FAK signaling rapidly and potently promotes mitochondrial function through STAT3
}

Nishant P. Visavadiya ${ }^{\dagger}$, Matthew P. Keasey ${ }^{\dagger}$, Vladislav Razskazovskiy, Kalpita Banerjee, Cuihong Jia, Chiharu Lovins, Gary L. Wright and Theo Hagg*

\section{Correction to: Cell Commun Signal (2016) 14:32 https://doi.org/10.1186/s12964-016-0157-7}

Unfortunately, after publication of this article [1], it was noticed that the Acknowledgements and Funding sections were incomplete. The Acknowledgements section currently reads, "We are grateful for the technical support by Aruna Visavadiya, Ying Li, and Rhesa Dykes" and the Funding section currently reads, "This work was supported by NIH grant NS45734 and ETSU medical school funds". The full, corrected sections can be seen below.

\section{Acknowledgements}

We are grateful for the technical support by Aruna Visavadiya, Ying Li, and Rhesa Dykes. Dr. Britta Engelhardt (Theodor Kocher institute) is thanked for providing the bEnd5 cells.

\section{Funding}

This work was supported by NIH grant NS45734 and in part by NIH grant C06RR0306551 and the ETSU College of Medicine.

Further to this, a duplicate image in Fig. 4e was reported. The correct image is presented in this correction article.
Published online: 20 April 2020

\section{Reference}

1. Visavadiya NP, Keasey MP, Razskazovskiy V, et al. Integrin-FAK signaling rapidly and potently promotes mitochondrial function through STAT3. Cell Commun Signal. 2016;14:32. https://doi.org/10.1186/s12964-016-0157-7.

The original article can be found online at https://doi.org/10.1186/s12964016-0157-7.

* Correspondence: haggt1@etsu.edu

${ }^{\dagger}$ Nishant P. Visavadiya and Matthew P. Keasey contributed equally to this work.

Department of Biomedical Sciences, Quillen College of Medicine, East Tennessee State University, Building 178, Maple Ave, PO Box 70582, Johnson City TN37614, USA

C C The Author(s). 2020 Open Access This article is licensed under a Creative Commons Attribution 4.0 International License, which permits use, sharing, adaptation, distribution and reproduction in any medium or format, as long as you give appropriate credit to the original author(s) and the source, provide a link to the Creative Commons licence, and indicate if changes were made. The images or other third party material in this article are included in the article's Creative Commons licence, unless indicated otherwise in a credit line to the material. If material is not included in the article's Creative Commons licence and your intended use is not permitted by statutory regulation or exceeds the permitted use, you will need to obtain permission directly from the copyright holder. To view a copy of this licence, visit http://creativecommons.org/licenses/by/4.0/. The Creative Commons Public Domain Dedication waiver (http://creativecommons.org/publicdomain/zero/1.0/) applies to the data made available in this article, unless otherwise stated in a credit line to the data. 
A

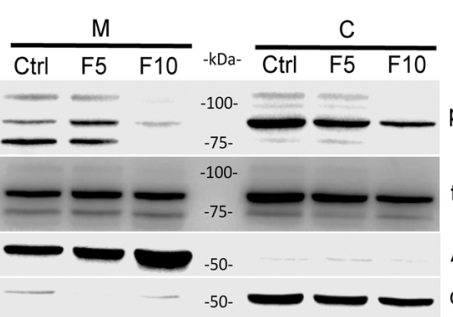

pS727-STAT3

tSTAT3

ATPase

a-tubulin

C

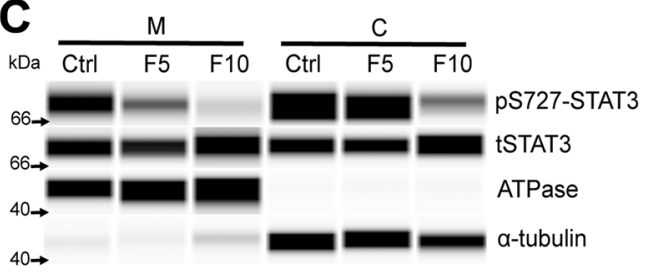

E

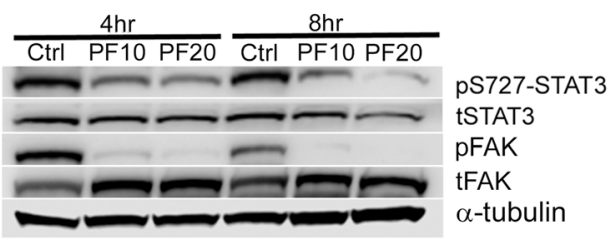

B

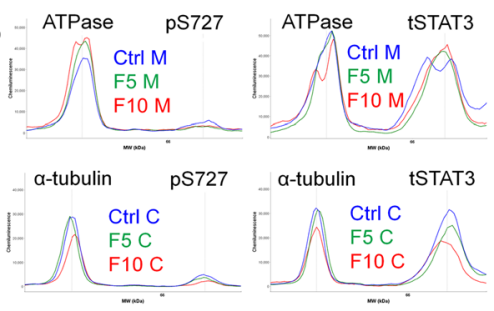

D
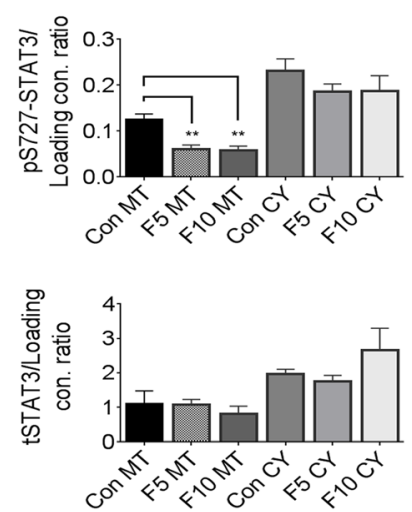

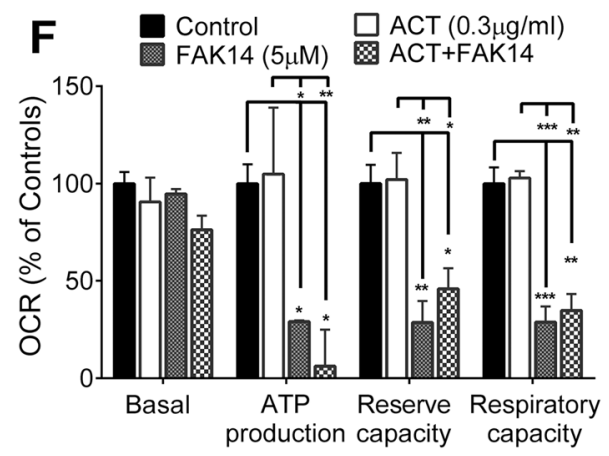

Fig. 4 FAK inhibits mitochondrial S727-STAT3 phosphorylation. a A $4 \mathrm{~h}$ FAK14 treatment of bEnd5 cells reduced pS727-STAT3 in both the mitochondrial and cytoplasmic fractions. Blots are representative for 5 experiments. $\mathbf{b}$ This reduction was confirmed by quantitative capillary western blotting with representative chemiluminescent spectrograms and synthetic bands (c). $\mathbf{d}$ Quantitation was performed of spectrograms confirmed a clear and significant decrease in pS727-STAT3 following $4 \mathrm{~h}$ FAK14 treatment in the mitochondrial fractions $(n=3)$. e Treatment with another more lipophilic FAK antagonist (PF573228: PF at 10 or $20 \mu \mathrm{M}$ ) for 4 or $8 \mathrm{~h}$ showed decreases in pS727-STAT3 in conjunction with decreased pFAK in whole cell lysates. $\mathbf{f}$ Incubation with the global transcriptional inhibitor actinomycin D $(0.3 \mu \mathrm{g} / \mathrm{ml}, 4 \mathrm{~h})$ did not significantly change mitochondrial bioenergetics under control or FAK14 conditions 